\title{
ANALISIS KESOPANAN TINDAK TUTUR DIREKTIF DALAM PEMBELAJARAN DARING KAJIAN: PRAGMATIK
}

\author{
Muhamad Alfin Alfiansyah ${ }^{1}$, Wahya ${ }^{2}$, Abu Sufyan ${ }^{3}$ \\ Fakultas Ilmu Budaya Universitas Padjadjaran \\ Surel: muhamad15038@mail.unpad.ac.id ${ }^{1}$ \\ wahya@unpad.ac.id ${ }^{2}$ \\ abu.sufyan@unpad.ac.id ${ }^{3}$
}

\begin{abstract}
Abstrak
Artikel ini berjudul Analisis Kesopanan Tindak Tutur Direktif dalam Pembelajaran Daring: Kajian Pragmatik. Penelitian ini membahas mengenai penggunaan tindak tutur direktif yang digunakan dalam sebuah interaksi antara guru dan siswa melalui media dalam jaringan (daring) menggunakan aplikasi Whatsapp. Pembelajaran daring merupakan metode pengganti pembelajaran di ruang kelas selama situasi pandemi Covid-19. Metode yang digunakan dalam penelitian ini adalah metode kualitatif, yaitu dengan menghasilkan data deskriptif berupa data tulisan secara sistematis, faktual, dan akurat.. Sumber data diambil dari riwayat percakapan antara guru dan siswa di SMPN 1 Ibun Kabupaten Bandung. Pengumpulan data dilakukan dengan menggunakan tangkapan layar dari ponsel guru mata pelajaran bahasa Sunda yang berperan sebagai narasumber. Penelitian ini bertujuan mengaplikasikan tuturan direktif yang mempunyai fungsi agar mitra tutur melakukan sesuatu dengan prinsip kesopanan serta menganalisis tuturan siswa yang baru menginjak masa transisi dari anak-anak ke remaja dengan memperhatikan penyampaian pesan teks kepada guru. Teori yang digunakan merupakan pandangan yang dikemukakan oleh Ibrahim (1993) dengan mengklasifikasikan tuturan direktif ke dalam enam bentuk klasifikasi, yaiturnarequiestivies, questions, requirement, prohibitives, advisories, dan pernissive dán pristro kesopanan yang dikemukakan oleh Leech (1993). Hasil dari penelitian ini menunjukkan interaksi lebih didominasi oleh tindak tutur yang fungsi sebagai pemberi saran (advisories) serta ditemukan banyak pelanggaran maksim kemurahan (generosity maxim) selama berlangsungnya pembelajaran daring.
\end{abstract}

Kata kunci: pragmatik, prinsip kesopanan, tindak tutur direktif, fungsi, perintah. 


\begin{abstract}
This study is entitled analysis politeness of directive speech act on the network study: pragmatic studies. The study discusses the use of directive speech act used during the interaction between teachers and students in online learning through the WhatsApp application. Online learning is a method for subtitute learning in the classroom during the covid-19 pandemic situation. The method used in this study is a qualitative method, which results in descriptive data of systematically, factual, and accurate written data. Data sources are drawn from the history of conversations between teachers and students in Junior High School Ibun in Bandung Regency. Data collection involves using the screenshots from the Sundanese teacher's phone. The aim of the study is to analyze the directive speech function that makes speech partners do something politely. As well as analyzing the speech of students who have just entered the transition period from children to adolescents how to speech to teacher with text massaging. The theories used are Ibrahim's (1993) six classification of directive speech; requestivies, questions, requirement, prohibitives, advisories, and permissive, and Leech's (1993) politeness principles theory. The results of the analysis show that the interaction is dominated by advisories speech act and a lot of generosity maxim violation during online learning.
\end{abstract}

Keywords: Pragmatic, politeness principles, directive speech act, function, order

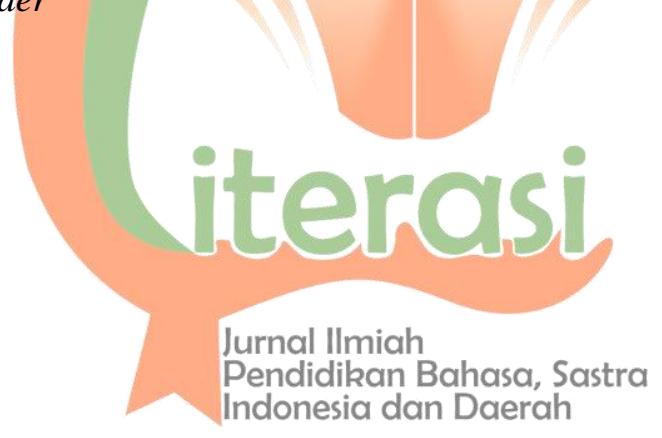




\section{PENDAHULUAN}

Bahasa merupakan anugerah dari Tuhan Yang Mahakuasa karena melalui bahasa, manusia dapat memahami satu sama lain dengan berkomunikasi, dan dapat saling menyampaikan pesan, perasaan, serta keputusan. Secara ilmiah, kajian bahasa diteliti dengan menggunakan ilmu linguistik. Keilmuan linguistik terbagi atas dua cabang yaitu mikrolinguistik dan makrolinguistik. Mikrolinguistik mempelajari unsur terkecil suatu bahasa dan berfokus pada kajian internal bahasa itu sendiri seperti fonem, morfem, sintaksis, semantik. Sementara itu, makrolinguistik membahas unsur bahasa secara luas serta mengaitkan hubungan dengan bidang keilmuan di luar bahasa.

Manusia sebagai makhluk sosial memerlukan komunikasi untuk menyampaikan informasi, berupa pesan, ide, ataupun gagasan dari satu individu ke individu lain. Bentuk komunikasi terdiri atas komunikasi verbal dan nonverbal. Komunikasi verbal menggunakan media bahasa yang berupa kata-kata, baik secara lisan maupun tulisan, sementara komunikasi nonverbal menggunakan gerakan anggota tubuh seperti gestur, mimik wajah, tindakan dan lain sebagainyănal

Pada umumnya komunikasi dilakukan secara verbal melalui media bahasa oleh karena itu penggunaan bahasa sangat penting dalam suatu interaksi sosial, bahasa yang baik tentu akan menghasilkan komunikasi yang baik pula. Oleh karena itu, penutur yang menuturkan bahasa tentu sangat memperhatikan tuturan yang disampaikan kepada mitra tutur, sebaliknya mitra tutur harus paham dengan konteks yang diungkapkan oleh mitra tutur. Dengan begitu, komunikasi akan berjalan dengan baik. Hubungan antara penutur dengan mitra tutur dalam ilmu linguistik dikaji dengan menggunakan kajian pragmatik.

Pragmatik adalah cabang ilmu linguistik yang berkonsentrasi mengenai makna konseptual yang disampaikan oleh penutur atau penulis dan ditafsirkan oleh lawan tutur yang berperan sebagai pendengar atau pembaca agar diketahui maksud tuturannya. Tindak tutur merupakan salah satu topik yang dibahas dalam pragmatik. Tindak tutur menghasilkan dampak psikologis terhadap mitra tutur. Implementasi teori pragmatik dapat diterapkan untuk penelitian di berbagai bidang, yaitu kedokteran, sosial kemasyarakatan, pendidikan dan lain sebagainya.

Dunia pendidikan menjadi fokus utama pada penelitian ini karena pada praktiknya pendidikan melibatkan interaksi antara guru dengan murid, pengajar dan yang diajar. Kegiatan belajar mengajar sangat dibutuhkan tujuannya agar siswa dapat menyerap ilmu yang diberikan oleh guru. Umumnya, kegiatan tersebut dilakukan di dalam ruang kelas, namun sejak adanya pandemi virus (coronavirus disease 2019) Covid-19 menuntut para guru dan siswa untuk mengadakan kegiatan belajar mengajar di rumah dengan memanfaatkan metode pembelajaran dalam jaringan (daring) melalui sambungan internet. Hal tersebut untuk mengantisipasi penyebaran virus agar tidak semakin meluas. Metode belajar yang digunakan oleh guru dan siswa dalam pembelajaran daring sangat beragam di antaranya aplikasi Zoom, Google Meet, Google Classroom, pesan Whatsapp, video pembelajaran dan lain 
sebagainya. Penggunaan teknologi tersebut adalah upaya agar pembelajaran tetap berjalan di tengah situasi pandemi dan jarak yang saling berjauhan.

Aplikasi Whatsapp umumnya digunakan untuk mengirim pesan teks (message), pesan suara (voice note), panggilan suara (voice call), dan panggilan video (video call) layanan tersebut memungkinkan adanya interaksi antar pengguna. Percakapan melalui aplikasi Whatsapp sendiri banyak dimanfaatkan oleh siswa saat pembelajaran daring, siswa memanfaatkan aplikasi tersebut untuk menanyakan tugas, mengirim bentuk visual tugas yang diberikan guru, dan berdiskusi di grup yang beranggotakan guru dan siswa-siswa kelas tersebut. Sumber data yang diamati dalam penelitian ini merupakan fungsi direktif yang digunakan pada saat percakapan guru dan siswa di SMP Negeri 1 Ibun Kabupaten Bandung. Mata pelajaran yang diajarkan adalah bahasa Sunda kelas 7. Fungsi tindak tutur direktif digunakan dalam penelitian ini pada saat guru dan siswa berinteraksi melalui jaringan internet. Data diperoleh dari tangkapan layar narasumber yang berprofesi sebagai guru mata pelajaran bahasa Sunda.

Penggunaan bahasa yang Jusopan merupakan hal yang penting dalam dunia pendidikan karena bahasa yang lebih sopan tingkat tuturnya dinilai lebih berpendidikan. Hal tersebut berlaku pada tuturan direktif yang ditemukan dalam interaksi di ranah pendidikan yang berfokus pada percakapan antara guru dengan siswa. Dalam interaksi tersebut, terdapat hubungan sosial yang asimetri, yaitu tingkat superioritas seorang guru dan inferioritas seorang murid. Seorang guru dalam tingkatan tersebut mempunyai wewenang untuk memberikan nasihat, mengajak, memerintah, melarang, memberikan izin, dan memberikan pertanyaan kepada siswa. Hal tersebut yang melatarbelakangi adanya penggunaan fungsi tuturan direktif di dalam ranah pendidikan.

Penelitian mengenai penggunaan tindak tutur direktif telah dilakukan oleh beberapa peneliti sebelumnya. Penelitian-penelitian tersebut di antaranya:

(1) Asra (2018) dalam prosiding Seminar Nasional yang bertajuk Kajian Bahasa, dan Pengajarannya membahas mengenai Analisis Tindak Kesantunan Direktif dalam Pesan WhatsApp. Penelitian tersebut menggunakan metode klasifikasi fungsi direktif dari Ibrahim (1993) yang mengklasifikasikan fungsi direktif ke dalam enam fungsi yaitu requestives, questions, requirements, prohibitives, permisives, dan advisories. Hasil penelitian tersebut menunjukkan dua hubungan sosial yang berkaitan dengan bentuk tindak kesantunan direktif dalam pesan WhatsApp yaitu hubungan simetris dan asimetris. Hubungan simetris menggunakan strategi positif dan negatif politeness sementara, hubungan asimetris posisi superior menggunakan strategi positif politeness untuk pertanyaan (questions), perintah (requirements), permintaan (requestivies), larangan (prohibitives), pemberian izin (permisives), 
nasihat (advisories), posisi inferior menggunakan strategi negatif politeness untuk bertanya dan meminta izin.

(2) Astuti (2017) dalam sebuah jurnal yang berjudul Kesantunan Tuturan Direktif dalam Interaksi Pembelajaran di SMA. Penelitian tersebut menggunakan teori dan panduan analisis berdasarkan teori tindak tutur direktif Bach dan Harnish. Penelitian tersebut bertujuan untuk mengetahui bentuk kesantunan direktif siswa SMA 1 Batu. Bentuk tuturan direktif yang digunakan yaitu direktif permintaan, direktif pertanyaan, direktif perintah, direktif larangan, direktif pemberian izin, dan direktif nasihat. Hasil dari penelitian tersebut guru melakukan kesantunan secara dominan melalui perintah, larangan, izin, dan nasihat. Sedangkan bentuk tuturan direktif dilakukan oleh guru dan siswa dengan mempertimbangkan aspek budaya.

Kedua penelitian tersebut menjadi tolok ukur peneliti untuk menggunakan teori sebelumnya untuk digunakan dalam penelitian ini. Penggunaan kalimat yang dituturkan oleh siswa SMA dengan SMP akan berbeda, menjadi sebuah latar belakang peneliti untuk mengetahui pola pikir serta bahasa yang diucapkan anak dalam tahap perkembangan saat memasuki masa awal remaja atau masa pubertas. Pada penelitian ini penulis melanjutkan penelitian dengan mengidentifikasi masalah mengenai interaksi secara jarak jauh melalui aplikasi pesan
Whatsapp dalam upaya menunjang proses pembelajaran daring serta penanda imperatif yang digunakan.

Menurut Ibrahim (1993, hlm. 28-33) fungsi direktif terbagi menjadi enam kategori yaitu (1) Requestives berfungsi untuk mengekspresikan keinginan agar mitra tutur bertindak. Kata kerja yang umumnya digunakan pada ekspresi ini adalah meminta, memohon, mengundang, mengajak. (2) Questions atau request merupakan bentuk permohonan kepada mitra tutur agar memberikan informasi; fungsi direktif ini umumnya digunakan untuk bertanya, mengintrogasi, menyelidik (3) Requirements mengekspresikan keinginan agar mitra tutur bertindak sesuai dengan keinginan penutur. Penutur memiliki kewenangan dalam memerintah dan mengomandoi atau mengatur mitra tutur. (4) Prohibitives kategori direktif ini berfungsi untuk melarang atau tidak melakukan sesuatu. (5) Permissives mengekspresikan suatu bentuk persetujuan yang diberikan penutur kepada mitra tutur; kategori ini dilatarbelakangi adanya kepercayaan penutur kepada mitra tutur (6) Advisories suatu ekspresi penutur yang dimaksudkan untuk memberikan saran kepada mitra tutur.

Prinsip kesopanan menurut Yule ig (2014, hlm. 104) sebagai suatu konsep yang tegas seperti gagasan 'tingkah laku sosial yang sopan' atau etiket, terdapat dalam budaya. Menurut (Leech, 1983, hlm. 104) dalam pendapatnya menyatakan bahwa sopan santun tidak hanya mengenai keberadaban saja, namun makna yang diperoleh dari sopan santun adalah kaitan yang hilang antara prinsip kerja sama dengan daya dan makna. Terdapat enam maksim yang menjadi prinsip dasar kesopanan bahasa dikemukakan 
oleh Leech (1993) maksim-maksim tersebut di antaranya, maksim kebijaksanaan (tact maxim), maksim kemurahan (generosity maxim), maksim penerimaan (approbation maxim), maksim kerendahan hati (modesty maxim), maksim kecocokan (agreement maxim), dan maksim kesimpatian (sympathy maxim).

Fokus utama penelitian ini menitikberatkan pada penggunaan fungsi tuturan direktif serta strategi kesopanan yang digunakan oleh penutur dan mitra tutur. Manfaat teoretis penelitian ini untuk mengklasifikasikan secara rinci mengenai penggunaan fungsi tindak tutur direktif, serta perilaku tutur yang dianalisis menggunakan strategi kesopanan. Manfaat praktis penelitian ini adalah untuk mengetahui perilaku interaksi guru dengan siswa melalui metode daring sebagai salah satu media pembelajaran jarak jauh. Data disajikan dalam bentuk penggalan percakapan yang telah diklasifikasikan berdasarkan fungsi tuturan direktif.

\section{METODE}

Penelitian ini dilakukan dengan tiga tahap, yaitu tahap pengumpulan data, analisis data, dan penyajian hasil analisis data.

Metode pengumpulan datap yang digunakan berupa metode Irsimak dengan teknik catat. Penulis menyimak percakapan melalui tangkapan layar yang dikirimkan oleh narasumber yang berprofesi sebagai guru bahasa Sunda kelas 7 di SMP Negeri 1 Ibun Kabupaten Bandung, Jawa Barat yaitu Raihani Rieska Dzulhijani (23 tahun) beserta siswa. Penulis mencatat tuturan dengan memperhatikan konteks tuturan direktif dari setiap percakapan melalui hasil tangkapan layar, kemudian menganalisis sesuai dengan teori yang dikemukakan oleh Ibrahim (1993) mengenai klasifikasi tindak tutur direktif dan prinsip kesopanan yang dikemukakan oleh Leech (1983). Proses pengamatan dan pengumpulan data dilakukan dari bulan Juli sampai Desember 2020, atau pada semester ganjil tahun ajaran 2020/2021.

Setelah data terkumpul, tahapan selanjutnya adalah menganalisis data. Metode analisis yang digunakan dalam penelitian ini menggunakan metode padan pragmatis dengan mitra tutur sebagai alat penentu. Hal tersebut sesuai dengan pendapat dari Sudaryanto (2015, hlm. 19) Kalimat perintah atau imperatif adalah kalimat yang diucapkan menimbulkan reaksi tindakan tertentu dari mitra wicaranya maka orang yang bersangkutan berada dalam jalur kerja metode padan pragmatis. Metode padan dibagi ke dalam lima sub jenis yaitu referensial, fonetis artikulatoris, translasional, ortografis, dan pragmatis.

Pada tahapan penyajian hasil analisis data, peneliti menentukan konteks kalimat melalui penggalan percakapan yang termasuk dalam kalimat perintah atau tindak tutur direktif yaitu kalimat yang bila diucapkan sakikan menimbulkan reaksi tindakan tertentu dari mitra tutur. Pengklasifikasian berdasarkan enam fungsi tindak tutur direktif, yaitu: (1) Requestivies (meminta); (2) Questions (bertanya untuk mendapatkan informasi); (3) Requirement (memerintah); (4) Prohibitives (melarang); (5) Advisories (memberi saran); (6) Permissive (memberi izin). 
Selanjutnya, peneliti menggunakan analisis prinsip kesopanan untuk mengetahui perilaku tutur yang memiliki perbedaan tingkat sosial yaitu guru dengan murid. Maksim yang digunakan sebagai berikut: maksim penerimaan; maksim kerendahan hati; maksim kecocokan; maksim kemurahan.

\section{HASIL DAN PEMBAHASAN}

Tindak tutur direktif dengan strategi kesopanan merupakan dasar utama dalam menganalisis data. Data disajikan berdasarkan tuturan direktif yang digunakan saat interaksi antara guru dan murid. Percakapan berlangsung dalam sebuah aplikasi pengirim pesan Whatsapp. Penyajian data dapat diklasifikasikan berdasarkan penggunaan tindak tutur direktif dan strategi kesopanan dengan pemenuhan dan pelanggaran maksim sebagai berikut.

\section{Analisis Data}

Analisis data disajikan dalam bentuk kategori fungsi tindak tutur direktif dan prinsip kesopanan.

\subsection{Fungsi Direktif Requestivies} (meminta):

(1) Siswa

:Assalamualaikum Indobuic hoyong nyuhunkeun tugas sundana soalna teu acan kenging videona 'Assalamualaikum bu mau minta tugas sunda karena saya belum dapat videonya'

(2) Siswa : buru lila b(e)lajar teh 'cepat, lama belajarnya'
Data (1) menunjukkan urutan teks percakapan antara murid dengan guru. Pada awal tuturan, murid mengucapkan salam dengan ucapan Assalamualaikum sebagai tindak ekspresif berupa fatis yang berfungsi untuk memulai percakapan dan sebagai penanda bahwa penutur merupakan pemeluk agama Islam, tujuan siswa menuturkan kalimat tersebut adalah untuk meminta tugas yang telah diberikan guru namun siswa tersebut belum mendapatkannya. Oleh karena itu, siswa tersebut meminta tugas kembali kepada guru.

Konteks kalimat tersebut dikategorikan sebagai bentuk tindak tutur direktif requirement (meminta). Hal tersebut dibuktikan dengan adanya penanda kata kerja (v) nyuhunkeun 'minta' tindak tutur yang dipakai oleh penutur untuk meminta orang lain melakukan sesuatu. Kata nyuhunkeun merupakan kata turunan dari kata dasar suhun dengan awalan alomorf $N$ (nasal) sebagai penanda bentuk aktif (Djajasudarma, 2013, hlm. 56) dan akhiran -keun dalam morfologi bahasa Sunda kata tersebut merupakan makna kategorial imperatif (Djajasudarma, 2013, hlm. 81)

Data (2) merupakan penggalan percakapan yang terdapat pada grup kelas 7 siswa meminta agar guru mempercepat waktu dimulainya pelajaran. Setelah beberapa menit, guru mengirimkan file berupa video pembelajaran materi bahasa Sunda yang telah disajikan untuk menunjang aktivitas belajar daring. Kalimat yang digunakan siswa dalam grup tersebut menggunakan kata buru berjenis kelas kata verba, diikuti kata lila 'lama' termasuk kelas kata adjektiva serta kata belajar teh 'belajar' verba dilengkapi partikel teh sebagai penegas. 


\subsection{Fungsi Questions (bertanya untuk mendapatkan informasi)}

(3) Siswa: Saha nya admin na pang ngalebetke(u)n ka grup Sunda abi te(u) acan ngerjake(u)n tugas 'siapa ya adminnya(?) tolong masukan ke grup Sunda saya belum mengerjakan tugas'

(4) Siswa: Aya tugas teu kamari soalna karek muka grup? 'apakah kemarin ada tugas soalnya baru membuka grup?'

Struktur kalimat untuk data (3) merupakan bentuk kalimat interogatif, hal tersebut dilatarbelakangi fungsi direktif questions yang meminta mitra tutur agar memberikan informasi melalui pertanyaan. Kalimat tersebut dikirim oleh siswa kepada guru untuk memberikan jawaban siapa yang menjadi admin di grup Whatsapp kelas.

Kata bantu tanya saha 'siapa' merupakan penanda untuk direktif questions penanda tersebut berada di awal kalimat yang mempunyai pola kalimat interogatif, kata -nya sebagai penegas dan adminna merupakan objek. Kemudian terdapat kata turunan bentuk verba pang ngalebetkeun prefiks pang bergabung dengan verba ngalebetkeun 'masukkan' yang mempunyai bentuk dasar verba lebet 'masuk' + sufiks keun yang mempunyai peran membentuk verba imperatif.

Data (4) mempunyai fungsi questions 'pertanyaan'. Kalimat tersebut diklasifikasikan ke dalam tuturan direktif questions karena terdapat penanda kata yang menuntut jawaban dari mitra tutur yaitu jawaban ya atau tidak.

\subsection{Direktif (memerintah) \\ Requirement}

(5) Guru: Perkenalkeun heula bageur upami nga WA ka guru téh 'perkenalkan diri terlebih dahulu anak baik, kalau mau menghubungi guru melalui WA (whatsapp)'

(6) Guru: Ai ibu miwarangna kumaha? Sesuai perintah atuh. Ti awal ge ibu nyarios, tugasna di buku catatan.

'Ibu memerintahkannya bagaimana? Harus sesuai perintah. Dari awal ibu sudah menyampaikan tugasnya di buku catatan.'

Data (5), guru memberikan kalimat direktif kepada siswa yang tidak menyebut identitasnya saat memulai percakapan dengan guru. Kalimat tersebut termasuk ke dalam bentuk tuturan direktif requirement atau perintah. Kalimat tersebut bertujuan agar siswa dapat dengan jelas memberitahukan siapa yang telah menghubungi. Keterangan pelaku diperlukan agar komunikasi tetap berlangsung antara siswa dengan guru.

Struktur kalimat tersebut merupakan kalimat imperatif karena terdapat sufiks -keun pada awal kalimat perkenal-keun secara bahasa hal tersebut termasuk dalam campur kode karena diawali oleh prefiks perkenal+keun yang termasuk ke dalam bahasa Indonesia sementara sufiks -keun dalam bahasa Sunda memiliki makna perintah. Kata Bageur 'baik' merupakan fungsi ekspresif untuk mempertahankan kalimat. Upami merupakan bentuk kata hubungan syarat dengan kata selanjutnya yaitu nga-wa. Kata WA merupakan bentuk 
abreviasi dari WhatsApp termasuk dalam kelas kata nomina yang menggunakan prefiks nga- yang bermakna aktif serta ' $k a$ guru teh' merupakan frasa eksosentris. Kalimat tersebut mempunyai makna bersyarat apabila hendak menghubungi guru, harus memenuhi perintah dari guru yaitu memperkenalkan diri.

Data (6) diawali dengan kalimat interogatif, namun kalimat tersebut tidak menuntut jawaban dari mitra tutur dan berfungsi sebagai pengingat kepada mitra tutur bahwa tugas tersebut sudah diingatkan. Pada kalimat sesuai perintah atuh yang berarti 'sesuai perintah' merupakan tuturan direktif requirement secara konteks kalimat tersebut merupakan penegasan bahwa siswa harus turut dengan yang diperintahkan sebelumnya. Penanda gramatikal untuk fungsi direktif requirement adalah sesuai perintah atuh. Kata 'sesuai' termasuk ke dalam kelas kata adjektiva yang memiliki makna sama. Kata perintah termasuk dalam kelas kata nomina yang memiliki arti perkataan yang digunakan untuk melakukan sesuatu. Diikuti partikel atuh sebagai penegas dalam bahasa Sunda kata atuh berfungsi sebagai kecap pangagét lamun kitu mah kalau begitu (Kamus Basa Sunda R.A Danadibrata 2009, hlm. 39). Jurnal Ilmiah

\subsection{Direktif Prohibitives (melarang)}

(7) Guru : tong kitu atuh nyariosna. Jiga sanes $s(a) r(e)(n) g$ guru 'jangan begitu bicaranya, seperti bukan dengan guru'

(8) Siswa : jangan gitu ga sopan 'jangan begitu tidak sopan'

Data (7) merupakan direktif larangan. Direktif larangan dapat diketahui melalui penanda yang digunakan yaitu berupa kata yang bermakna sebagai sebuah anjuran. Penggunaan kata tong dalam bahasa Sunda mempunyai makna jangan, fungsi guru sebagai orang yang mempunyai wewenang untuk melarang muridnya melakukan sesuatu yang tidak layak diucapkan oleh murid.

Data (8) merupakan reaksi seorang siswa kepada temannya yang ada dalam satu grup percakapan kelas 7. Pada percakapan sebelumnya siswa yang dilarang berbicara seperti itu mengungkapkan kalimat tugas mana tugas yang ditujukan kepada guru, karena orang yang selalu memberi tugas sekolah adalah guru. Penutur merespon dengan tanggapan jangan gitu ga sopan. Jangan merupakan penanda untuk direktif prohibitives (melarang) gitu 'begitu' adalah ungkapan atas perilaku tutur temannya. Sementara, kata ga sopan 'tidak sopan' merupakan tindak tutur asertif atas perilakunya atau untuk menjelaskan bahwa hal tersebut tidak pantas diucapkan.

1.5 Direktif Advisories (memberikan saran)

(9) Siswa : Bu abi di anggap hadir nya da ti nu grup teu kasebatkeun

'bu saya dianggap hadir saja ya, karena di grup tidak disebutkan'

(10) Guru : sabar bageur. Éta ku ibu nuju dikirim tugasna. Loading da ibu teh ngirim ka 11 grup 'sabar ya. Ibu sedang mengirim tugasnya. Loading (ing: memuat) soalnya ibu mengirim ke 11 grup'

(11) Guru : kedah sopan nga WA ka guru mah. Ucapkeun salam 
heula. Terus perkenalkan diri

'Harus sopan menghubungi lewat Whatsapp ke guru. Ucapkan Salam terlebih dahulu. Lalu perkenalkan diri.'

(12) Guru : Ih naha atuh. Ka rerencangan atuh ibu kedah ngirim hiji2 maenya. Ieu ge atos dikirim ka 11 grup kelas teh.

'Ih kenapa? Minta ke teman saja, masa ibu harus mengirim satu satu. Ibu sudah mengirim ke 11 grup'

Penggalan percakapan data (9) merupakan tuturan siswa kepada gurunya yang bertujuan untuk menyarankan guru agar dia dianggap hadir pada saar mengikuti kegiatan sekolah daring. Data (8) menggunakan penanda gramatikal hadir nya sebagai penanda bentuk direktif advisories partikel -nya dalam bahasa Sunda berarti ya atau ungkapan agar mitra tutur menyetujui argumen penutur.

Data (10) merupakan penggalan percakapan yang digunakan guru kepada muridnya agar bersabar. Frasa sabar bageur merupakan frasa adjektiva, penggunaan dua kata tersebut dikategorikan sebagai fungsi direktif advisories karena memiliki fungsi untuk menyarankan siswa agar bersabar serta kata bageur 'baik' memiliki fungsi ekspresif memuji siswa yang telah didiknya.

Data (11), guru memberikan saran yang ditujukan kepada siswa yang telah menghubungi melalui pesan Whatsapp. Isi dari data (11) sama dengan data 4 yaitu menyarankan untuk memperkenalkan diri terlebih dahulu dikarenakan guru tidak mengetahui siapa yang mengirim pesan tersebut. Struktur pembentuk kalimat data (11) membentuk kalimat imperatif. Penanda gramatikal untuk tuturan data (11) berbentuk frasa kedah sopan 'harus sopan' merupakan frasa adjektiva.

Data (12), pemberian saran diberikan oleh guru kepada siswa agar siswa tersebut meminta tugas kepada temannya saja karena tugas tersebut telah dikirim ke masing-masing grup kelas. Siswa tersebut belum mendapatkannya dengan alasan baru bergabung di grup obrolan kelas. Jadi guru menyampaikan tuturan direktif advisories $k a$ rerencangan atuh 'ke teman saja'

\subsection{Direktif Permissive (memberikan} izin)

(13) Guru : Sok atuh rapihkeun absenna 'sila rapikan absennya'

Data (13), kalimat tersebut termasuk ke dalam bentuk tuturan direktif yang berfungsi untuk memberikan izin kepada mitra tutur untuk melakukan sesuatu. Guru mempersilakan muridnya agar merapikan absensi kelas yang tidak beraturan. Penanda gramatikal yang digunakan sebagai direktif permissive adalah verba sok atuh iơsilakan kalau begitu' kata tersebut mempunyai makna memberikan wewenang untuk melakukan sesuatu kepada mitra tutur, verba sok atuh merupakan gabungan dari kata sok + atuh dalam bahasa Sunda kata atuh disebut sebagai kecap pangagét (Kamus Basa Sunda R.A Danadibrata 2009, hlm. 39) kata atuh mempunyai arti lamun kitu mah 'kalau begitu'. Kemudian diikuti frasa verba rapihkeun absenna 'rapikan absennya' yang memberikan keterangan kalimat 
sebelumnya yaitu sebagai makna imperatif untuk memberikan perintah agar menyusun kembali absen yang tidak beraturan.

\section{Strategi Kesopanan}

Strategi kesopanan digunakan untuk mengetahui perbedaan status sosial, perilaku, dan etika dalam sebuah percakapan antara guru dengan siswa. Strategi kesopanan yang digunakan meliputi, pemenuhan maksim dan pelanggaran maksim.

\subsection{Pemenuhan Maksim}

\subsubsection{Pemenuhan Maksim kemurahan (Generosity Maxim)}

Siswa

(5) Guru

: Assalamualaikum bu. Kalau bahasa Sunda harus membuat absen lagi?

: waalaikumsalam.

Ieu sareng saha?

Perkenalkan heula

bageur upami nga WA ka guru téh 'Waalaikumsalam. Ini dengan siapa? perkenalkan diri terlebih dahulu anak baik, kalau mau menghubungi Jurguru melalui Ind WA (whatsapp)'

Data percakapan tersebut diawali oleh siswa yang menanyakan mengenai absensi mata pelajaran bahasa Sunda. Kalimat tersebut diawali dengan pengucapan salam yaitu Assalamualaikum yang bermakna sebuah doa agar senantiasa selamat dan sejahtera. Kemudian, guru menjawab salam, dilanjutkan dengan menjawab pertanyaan dari siswa perkenalkan heula bageur upami nga WA ka guru teh 'perkenalkan diri terlebih dahulu anak baik, kalau mau menghubungi melalui WA (whatsapp) percakapan antara guru dengan siswa tersebut telah memenuhi maksim kemurahan karena kata bageur 'baik' merupakan bentuk ekspresif dalam bahasa Sunda, kata tersebut memiliki makna konotatif tujuannya untuk memaksimalkan rasa hormat kepada orang lain, hal tersebut disebabkan perilaku siswa yang tidak sesuai dengan yang diharapkan oleh guru.

(10) Guru : sabar bageur. Éta ku ibu nuju dikirim tugasna. Loading da ibu teh ngirim ka $11 \quad$ grup 'Sabar, ibu sudah mengirimkan tugasnya. Masih menunggu karna ibu mengirim ke 11 grup.'

Ungkapan tersebut tergolong ke dalam tuturan direktif yang berfungsi memberi saran (advisories). Kalimat tersebut dituturkan oleh guru yang bertujuan untuk menenangkan siswa agar bersabar. Penggunaan kata bageur sama dengan data sebelumnya dan telah memenuhi maksim kemurahan.

\section{miah}

\subsection{2} Kesepakatan (Agreement maxim)

(12) Guru : Ih naha atuh. ka rerencangan atuh ibu kedah ngirim hiji2 maenya. Ieu ge atos dikirim ka 11 grup kelas teh.

'Ih kenapa? Minta ke teman saja, masa ibu harus mengirim satu 
satu. Ibu sudah mengirim ke 11 grup'

Siswa : muhun bu

'Baik, bu.

Data riwayat percakapan tersebut menunjukkan siswa menyetujui saran yang dituturkan oleh guru untuk menanyakan tugas ke teman satu kelas karena guru telah mengirim tugas tersebut ke-11 grup, percakapan tersebut telah memenuhi maksim kesepakatan.

Siswa

(13) Guru

: Ass, Bu abi dianggap hadir nya da tinu grup teu kasebat

'Ass, bu saya dianggap hadir, ya karena di grup tidak terpanggil'

: Sok atuh rapihkeun absenna

'sila rapikan absennya'

Data (13) merupakan ekspresi saat guru menyetujui permintaan siswa namun terdapat syarat yang harus dipenuhi oleh siswa yaitu merapikan kembali absennya. Pada percakapan sebelumnya, siswa menggunakan tuturan direktif advisories yang berfungsi memberi saran. Percakapan tersebut memenuhi maksim kesepakatan, kesepakatan tersebut disetujui oleh guru yang mengabulkan permintaan saran dari siswa.

\subsection{Pelanggaran Maksim}

\subsubsection{Pelanggaran Maksim Kemurahan (generosity maxim)}

(2) Siswa : buru lila b(e)lajar teh 'cepat, belajarnya sudah lama nih'
Tuturan yang digunakan siswa melanggar prinsip kesopanan yaitu maksim pujian karena tidak terdapat sapaan honorifik berupa bu atau pak. Serta tingkat tutur yang menggunakan bahasa loma 'bahasa yang digunakan untuk teman sebaya'. Konteks tuturan tersebut ditujukan kepada guru karena siswa tersebut meminta agar mulainya waktu pembelajaran dipercepat.

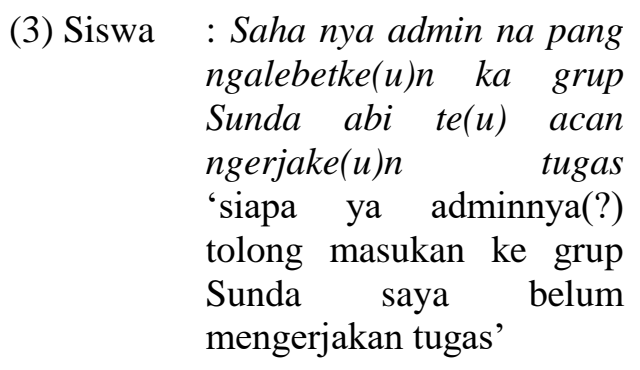

Data tersebut siswa menggunakkan kalimat interogatif dengan penanda kata saha 'siapa' dalam kalimat tersebut tidak terdapat strategi penghormatan yang ditujukan untuk guru yaitu berupa sapaan "bu" atau "pak". Tanggapan Guru terhadap kalimat pertama dengan tuturan direktif requirement "kedah sopan nga WA ka guru mah. Ucapkeun salam heula. Terus perkenalkan diri" 'harus sopan mengirim WA ke guru. Ucapkan salam terlebih dahulu. Lalu perkenalkan diri' kalimat tersebut mengekspresikan keinginan agar mitra tutur bertindak, hal itu dilatarbelakangi penutur memiliki kewenangan yang lebih tinggi dari mitra tutur.

(4) Siswa: Aya tugas teu kamari soalna karek muka grup? 'apakah kemarin ada tugas soalnya baru membuka grup?'

Data (4) diawali percakapan tanpa kalimat salam dan tanpa sapaan berupa 
"bu atau pak" pada tuturan kedua murid tersebut membuat sebuah kalimat pertanyaan mengenai pelajaran bahasa Sunda. Guru menanggapi dengan memberikan tuturan direktif requirement. Simpulan dari analisis data (4) bahwa murid tersebut melanggar maxim pujian (approbation maxim) karena tidak menggunakan honorifik berupa sapaan di awal percakapan.

\subsubsection{Pelanggaran Maksim Penerimaan}

(1)Siswa : Assalamualaikum bu hoyong nyuhunkeun tugas sundana soalna teu acan kenging videona

'Assalamualaikum bu mau minta tugas sunda karena saya belum dapat videonya'

Guru: Waalaikumsalam aya dina grup videona. Saha ieu?

'Waalaikumsalam. Ada di grup videonya. Ini siapa?

Siswa: Teu aya bu soalna masuk grupna telat. Enri Gunawan $7 \mathrm{j}$

'Tidak ada bu soalnya saya masuk grupnya telat. Enrri Gunawan $7 \mathrm{j}$

Pada percakapan tersebut, siswa meminta video berisi mater pembelajaran yang tidak sempat dia terima dengan alasan terlambat bergabung dengan grup kelas. Guru saat diminta untuk mengirim tugas dengan tuturannya tidak langsung memberikan namun, memberi pertanyaan kembali karena siswa yang tidak sempat memperkenalkan diri di awal percakapan. Data tersebut melanggar maksim penerimaan karena dalam maksim tersebut peserta tutur harus memaksimalkan kerugian terhadap diri sendiri. Dalam hal tersebut guru seharusnya memberikan tugas sesuai yang diminta oleh siswa.

\subsubsection{Pelanggaran Maksim Kesepakatan}

Siswa : Bu wios teu na polio g(e) asalkan dikempelkeun $\mathrm{ka}$ ibu da tos terlanjur

'Bu tidak apa apa menggunakan polio, asalkan dikumpulkan ke ibu, karena sudah terlanjur'

(6) Guru: Ai ibu miwarangna kumaha? Sesuai perintah atuh. Ti awal ge ibu nyarios, tugasna di buku catatan. 'Ibu memerintahkannya bagaimana? Harus sesuai perintah. Dari awal ibu sudah bilang tugasnya di buku catatan.'

Pada data tersebut, Siswa memberikan sebuah kalimat introgatif dengan penanda kata teu 'tidak' yang menuntut jawaban ya atau tidak, artinya mendapat persetujuan guru atau tidak. Dalam tuturan tersebut siswa melangar maksim kesepakatan karena sebelumnya guru telah memerintah untuk mengerjakan tugas tersebut di buku catatan. Sehingga tidak terdapat kecocokan dalam percakapan tersebut.

\subsubsection{Pelanggaran Maxim Kerendahan hati}

(7) Guru : tong kitu atuh nyariosna. Jiga sanes $s(a) r(e)(n) g$ guru 'jangan begitu bicaranya, seperti bukan dengan guru' 
(11) Guru : kedah sopan nga WA ka guru mah. Ucapkeun salam heula. Terus perkenalkan diri 'Harus sopan menghubungi lewat Whatsapp ke guru. Ucapkan Salam terlebih dahulu. Lalu perkenalkan diri.'

Data 7 dan data 11 guru menggunakan tuturan direktif yang berfungsi sebagai larangan (prohibitives) dan direktif yang berfungsi untuk memerintah (requirement). Kedua data tersebut dapat dikategorikan melanggar maksim kerendahan hati, karena dalam prinsip tersebut seorang penutur memaksimalkan ketidakhormatan kepada diri sendiri dan meminimalkan rasa hormat kepada orang lain, namun dalam konteks tersebut guru berusaha untuk mengajarkan sopan santun dan rasa hormat terhadap orang yang lebih tua terlebih sebagai pengajar. Jadi, secara pragmatik tuturan tersebut melanggar maksim namun di sisi lain sikap dari guru tersebut memberikan arahan agar siswa lebih menghormati orang yang lebih tua.

\subsubsection{Pelanggaran Maksim}

Kebijaksanaan (Agreement Maxim)

Siswa Z : Tugas mana tugas(?) 'mana tugasnya? (tidak kunjung diberikan)'

(8) Siswa $\mathrm{S}$ : jangan gitu ga sopan 'jangan begitu tidak sopan'

Data percakapan tersebut memperlihatkan percakapan antara siswa dengan inisial $\mathrm{Z}$ dan siswa dengan inisal $S$, pecakapan tersebut berlangsung di sebuah grup obrolan
Sunda kelas 7K. Siswa Z menanyakan tugas yang belum diberikan dengan menggunakan ungkapan tugas mana tugas 'tugasnya mana?'. Dua menit kemudian, siswa dengan inisial $S$ mengingatkan siswa $\mathrm{Z}$ agar lebih sopan saat bertutur di grup kelas menggunakan fungsi direktif larangan (prohibitives) jangan gitu gak sopan. Hal tersebut melanggar maksim kebijaksanaan karena dalam tuturan tersebut sama sekali memaksimalkan kerugian orang lain karena mengeluarkan kata yang tidak sopan saat meminta tugas.

(14) Siswa : Bu minta tugas 2,3,4

Guru : saha ieu (?) 'siapa ini?'

Siswa : Hafidz roihan kelas $7 \mathrm{~g}$

Guru : Nga wa ka guru teh ucapkeun salam heula. Anggo bahasa anu sopan

'ucapkan salam terlebih dahulu sebelum mengubungi melalui whatsapp (wa). Gunakan bahasa yang sopan'

Kutipan percakapan tersebut merupakan contoh kalimat direktif drequestives. Siswa meminta tugas dengan nomor urut 2, 3, 4 kepada guru tanpa adanya ucapan salam atau memperkenalkan diri saat menghubungi guru melalui aplikasi Whatsapp. Tuturan tersebut melanggar maksim kebijaksanaan karena tuturan yang dinilai secara langsung kepada gurum karena dalam maksim kebijaksanaan 
semakin tuturan itu tidak langsung dan panjang maka semakin sopan.

\section{PENUTUP}

\section{Simpulan}

Berdasarkan data yang telah dianalisis, data yang telah dihimpun telah memenuhi enam fungsi kategori direktif. Penggunaan tuturan direktif digunakan oleh kedua penutur, baik guru maupun siswa dalam interaksinya. Interaksi yang digunakan memberikan pandangan mengenai aktivitas pembelajaran daring.

Identifikasi kalimat berdasarkan fungsi ditentukan dari konteks kalimat tersebut. Penggunaan fungsi requestivies terdapat pada penanda dalam kalimat yaitu adanya kata minta. Penutur meminta sebuah permohonan agar mitra tutur mengabulkan apa yang diminta. Fungsi direktif questions, penutur memberikan suatu pertanyaan penanda yang digunakan dapat berupa kata bantu tanya atau berupa tuturan yang menuntut kepada suatu jawaban, hal tersebut yang menjadikan fungsi tersebut termasuk dalam tuturan direktif. Tuturan direktif requirement digunakan oleh orang yang lebih tinggi tingkatannya atau memiliki superioritas. Hal tersebut dapat dibuktikan pada data yang dianalisis tuturan tersebut digunakan oleh guru yang mempunyai wewenang untuk memerintah.

Fungsi direktif prohibitives digunakan sebagai cegahan atau larangan terhadap mitra tutur yang dianggap tidak sesuai dengan yang dikehendak, Pada fungsi tuturan prohibitives penutur menggunakan kata "jangan" yang mempunyai makna untuk mencegah mitra tutur melakukan perilaku yang tidak sesuai dengan kehendaknya. Dari data yang ditemukan, larangan tersebut lebih menekankan kepada perilaku tuturan yang digunakan oleh mitra tutur terhadap guru. Pada fungsi direktif advisories penutur mengutarakan keinginan secara implisit karena berkaitan dengan saran agar mitra tutur mau menerima saran tersebut. Penanda yang ditemukan pada data bersifat penekanan kalimat dan kata yang terkesan memuji. Penggunaan tuturan direktif permissive atau memberikan izin dilakukan pada saat guru mengizinkan siswa untuk menjadi kegiatan guru yaitu berkaitan dengan absensi oleh karena itu diartikan seorang penutur yang mempunyai wewenang namun pengerjaanya dilakukan oleh orang lain. Penelitian lebih mendalam mengenai fungsi tindak tutur direktif juga dapat diimplementasikan dalam teks maupun narasi iklan berbahasa Sunda. Penyampaian iklan dapat berupa tuturan langsung maupun tidak langsung.

Pelanggaran maksim dan pemenuhan maksim ditemukan dalam analisis data percakapan. Penggunaan kalimat direktif dengan mempertimbangkan aspek kesopanan menjadi fokus utama penelitian ini. Hasilnya, terdapat 5 data yang dinilai memenuhi maksim, sementara 9 data melanggar maksim kesopanan dalam tindak tutur. Pemenuhan maksim yang terdapat pada maksim penerimaan, kemurahan, dan kesepakatan. Sementara, maksim yang banyak dilanggar adalah maksim kemurahan atau maksim yang berkaitan dengan rasa hormat. Interaksi siswa dan guru dipengaruhi kurangnya pengetahuan mengenai sistematika penulisan melalui aplikasi pesan dan kurangnya adaptasi 
tingkat tutur yang digunakan oleh siswa kepada guru.

\section{DAFTAR PUSTAKA}

Asra, A. Andriyani. (2018). Analisis tindak kesantunan direktif dalam pesan whatsapp. Prosiding. Seminar Nasional Kajian Bahasa, Sastra dan Pengajarannya. Surakarta. 13 Mei 2018. Hal 303-309.

Astuti, M. P., Widodo HS, dan Sunoto. (2017). Kesantunan tuturan direktif dalam interaksi pembelajaran di sma. Jurnal Pendidikan Vol. 2 Nomor 3. hlm. 434-439.

Badudu, J.S dan Zain. (1994). Kamus Umum Bahasa Indonesia. Jakarta: Pustaka Sinar Harapan.

Hitijahubessy, Michele. (2019). Prinsip-prinsip kesantunan berbahasa dalam interaksi antara sesama penutur ambon. Gramatikal. Volume 7, Nomor 1. 10-15.

Ibrahim, A. S. (1993). Kajian Tindak Tutur. Surabaya: Usaha Nasional.

Leech, G. N. (2014). The Pragmatic of Politeness. New York: Oxford University Press 2014.

Moleong, L. J. (2014). Metodologi Penelitian Kualitatif. Bandung: PT. Remaja Rosdakarya.

Rahardi, R. K., Setyaningsih, Y., \& Dewi, R. P. (2014). Kata fatis penanda ketidaksantunan pragmatikikan Bahasa, Sastra dalam ranah keluarga. Adabiyyât:sia dan Daerah

jurnal bahasa dan sastra, 13(2), 149-175.

Sekarsany, A., Darmayanti, N., \& Suparman, T. (2020). Tindak tutur ilokusi pada proses kelahiran dengan teknik hipnosis (Hypnobirthing). Metahumaniora, 10(1), 14-26.

Sudaryanto. (2015). Metode dan Aneka Teknik Analisis Bahasa.
Yogyakarta: Sanata Dharma University Press.

Sugiarti, M., Rahayu, N., \& Wulandari, C. (2017). Analisis ketidaksantunan berbahasa di smp negeri 18 kota bengkulu. Jurnal Ilmiah KORPUS, 1(2), 150-156.

Suherman, E. (2008). Prinsip kerja sama, kesopanan, dan ironi dalam masyarakat jepang: sebuah tinjauan dari dimensi sosiopragmatis. LITE: Jurnal Bahasa, Sastra, dan Budaya, 4(1), 24-35.

Tarigan, H. G. (2009). Pengkajian Pragmatik. Bandung: Angkasa.

Verhaar, J.W.M. (1999). Pengantar Linguistik. Yogyakarta: Gadjah Mada University Press.

Yule, George. (2014). Pragmatik. Yogyakarta: Pustaka Pelajar Offset. 